\title{
EXPECTATIONS OF A POST-WWII DEPRESSION
}

\begin{abstract}
The forecast of a Post-WWII depression is contrasted against the vigorous growth that actually happened. Economists called for continued control over the economy to prevent the feared depression. But, in spite of the warning, returning soldiers were rapidly demobilized and the economy decontrolled. While economists dismissed indications toward the end of the war of pent-up demand as unsustainable, pent-up demand played an important role in the smooth transition from a wartime to a peacetime economy. Indicators of pent-up demand included buying plans and the accumulation of liquid assets. This study tracks expectations of a post-war depression of the general public, business and economists during this period. It shows that, in 1947, all three groups expected a recession, if not a depression. Yet, no such thing occurred. In the case of the general public, a time series of expectations is extracted from heterogeneous survey data.
\end{abstract}

Keywords: Post-war depression, consumer confidence, business confidence, buying plans, rationing

doi: 10.2478/sho-2021-0006

\section{INTRODUCTION}

As the United States prepared for the end of WWII, economists warned that the country would return to depression without continued massive government spending and controls over the economy. Samuelson P.A. [1943: 51] described what would come as 'the greatest period of unemployment and industrial dislocation which any economy has ever faced.' (italics in the original) But, ignoring their warnings, the returning soldiers were demobilized and the federal government's apparatus for controlling the economy was dismantled. The economy then quickly re-organized itself for private production and grew vigorously. At about the same time 
a similar "economic miracle" took place in western Germany; and, in the United Kingdom, where Fabian Socialists were influential, the economy slumped.

Higgs R. [2006] investigated the extraordinary duration of the Great Depression in the United States, the strange prosperity of World War II, and the vigorous growth of the economy following the war. ${ }^{1}$ He attributes the extraordinary duration of the Great Depression to uncertainties about future taxes and regulations given the animus of President Franklin D. Roosevelt and his administration toward private business. Businessmen hoarded cash. Private investment spending collapsed. From 1929 to 1932, gross private investment expenditures fell from 17.2 to 3.1 percent of GDP. From 1932 to 1941, private investment rose and fell along with the economy.

While the economy fell and rose and then fell and rose again during the 1930s, it continued to underperform relative to its trend. The unemployment rate, for example, remained above 10 percent through 1941. This illustrates the former distinction of a depression (a long period of depressed economic conditions) from a recession (the period during which GDP and other broad measures of economic conditions are falling). In contrast, nowadays, a depression is sometimes conceived merely to be a severe recession (e.g., a prolonged and/or particularly sharp fall, as characterized the period from 1929 to 1933).

With the entry of the U.S. into the war, employment surged because of a reduction of unemployment and entry into the labor force. However, consumer spending was restrained by rationing, and private investment averaged only 5.1 percent of GDP during 1942-1945. Forecasting the immediate post-war period was challenging because of the unusual circumstances of the war. ${ }^{2}$

Returning to Higgs' narrative, when Harry S. Truman succeeded Roosevelt as President, he brought a more pragmatic approach to government. The combination of pent-up demand and reasonable prospects of profit coaxed cash out of hordes and into investment. Private investment grew sharply and averaged 16.5 percent of GDP during 1946-1951. Higgs R. [2006: 25] summarizes his argument thusly,

${ }^{1}$ Higgs' analysis differs from what might be viewed as the mainstream view, as discussed by Romer C. [1993].

2 Hamilton J.D. [1992], Klug A. et al [2005], and Mathy G., Stekler H. [2017, 2018] discuss forecasts during the Great Depression. 
From 1935 through 1940, with Roosevelt and the ardent New Dealers who surrounded him in full cry, private investors dared not risk their funds in the amounts typical of the late 1920s. In 1945 and 1946, with Roosevelt dead, the New Deal in retreat, and most of the wartime controls being removed, investors came out in force.

Higgs tracks economic confidence in part with periodic surveys. For example, he cites a March 1939 survey of the general population “Do you think the attitude of the Roosevelt administration toward business is delaying business recovery?" 54 percent replied "yes," 26 percent said "no," and the rest had no opinion [Higgs R. 2006: 16]. Higgs also relies on traditional historical methods of inferring public opinion, citing Krooss H.E. [1970], Collins R.M. [1981], Fearon P. [1987] and Brinkley A. [1995], among others.

This paper extends on Higgs' work. It uses survey data to track public opinion concerning the economy through the immediate post-war period. There were a total of 31 surveys from 1944 to 1950 concerned with the public's expectations of a post-war recession. Although the questions asked were diverse, an internally-consistent time series can be inferred from the data collected by these surveys. Surveys of business and of economists are also tracked.

The next section looks at economic plans at the time the U.S. entered World War II. After that, the paper examines the accumulation of deferred demand during the war. The paper then tracks public opinion regarding the possibility of a post-war depression. The paper concludes with a discussion of the policy decisions made at the war's conclusion, and the performance of the economy.

\section{PLANNING FOR WAR}

Soon following the entry of the United States into World War II, the federal government took direct control of much of the economy, and regulated much of the rest of the economy through conscription, wage and price controls, and rationing [Bartels A.H. 1980; Evans P. 1982, Folsom B.W., Folsom A. 2011; Galbraith J.K. 1952; and Rockoff H. 1984]. The overall plan included a system of selective service to provide the manpower needed both by the military and industry, the direct operation of factories capable of war production, and the suppression of civilian demand through rationing. The purpose of rationing was to assure people access to key goods at controlled prices, in addition to suppressing civilian de- 
mand. The next few years featured extraordinarily high employment, production and income, with much of the income effectively forced by rationing into savings.

Underlying the direction of the economy was the "Victory Plan" of 1941. This plan outlined the requirements for fielding an enormous ground force, a navy equal to all other navies in the world combined, and an air force similarly equal to all other air forces in the world combined [Kirkpatrick C.E. 1980].

Prior to entering the war, the United States faced the prospect of waging war against Germany, Italy, Japan and the Soviet Union, along with their lesser allies and subordinated states, aided only by a United Kingdom laid prostrate by Germany, the United Kingdom's commonwealth nations, and a China laid prostrate by Japan. Many people remember Prime Minister Winston Churchill's line, in a 1940 speech, "We shall fight on the beaches, we shall fight on the landing grounds, we shall fight in fields and in the streets, we shall fight in the hills, we shall never surrender." What he went on to say after that should also be remembered.

... and if, which I do not for the moment believe, this island or a large part of it were subjugated and starving, then our empire beyond the seas, armed and guarded by the British Fleet, will carry on the struggle until in God's good time the New World with all its power and might, steps forth to the rescue and liberation of the Old. [International Churchill Society 1940].

Although Churchill said he refused to allow himself to believe it, he considered that Great Britain might be knocked out of the war. Then, what would happen? The New World would come to the rescue of the Old. Churchill was obviously referring to the United States. Yet, the United States had not yet entered the war. Nor had Germany yet invaded the Soviet Union.

In June 1941, with the invasion of the Soviet Union by Germany, the logistical picture as well as the military picture changed dramatically. No longer did the United States plan to alone confront an evil alliance stretching across the entire Eurasian landmass. Instead, the United States, if and when it entered the war, would be joined by the Soviet Union and a still intact United Kingdom. In addition, China continued to resist conquest by Japan, even as a civil war was getting underway within China.

The American war plan therefore shifted to becoming "the arsenal of democracy." ${ }^{3}$ This revised plan meant the U.S. would organize and sup-

\footnotetext{
${ }^{3}$ Not that the Soviet Union or Chiang Kai-shek's China were democracies.
} 
ply not only its own military forces, but also supply much of the weapons and munitions of its allies. While the new plan continued to include an air force and navy each equal to all the other navies and air forces of the rest of the world combined, the ground forces were to be expanded to "only" about 90 divisions in order to reserve manpower for U.S. industry. In real time, this was called "the 90 division gamble."

From an apparent standing start, ${ }^{4}$ the United States built up enormous military forces. It supplied these forces and much of the material support needed by its allies. While most historians point to the military battles of the war, the war was also won in the factories and the shipyards. And, to be the arsenal of democracy, victory required empty new car lots and empty department store shelves.

\section{DEFERRED DEMAND}

In accordance with the Victory Plan, production of private automobiles, household appliances and furniture were suspended "for the duration" (of the war). So too was new home construction. As the war continued, the stocks of durable consumer goods grew older, increasingly in need of replacement. Households were concurrently amassing savings in the form of war bonds and traditional liquid assets.

Evidence accumulated of enormous deferred demands by households for durable consumer goods and new homes. Perhaps the most authoritative evidence were the surveys of urban consumers and farmers conducted by the Bureau of the Census on behalf of the War Production Board [Noyes C.E., Hilgard E.R. 1946]. These were surveys of 5,000 households, allowing meaningful cross-tabulations by region and type of household.

The First Survey of Consumer Requirements was conducted during November 1943. It found, among other things, that scotch tape was most frequently mentioned in short supply. Alarm clocks were most frequently mentioned among items posing an inconvenience or hardship [Noyes C.E., Hilgard E.R. 1946: 263]. The other surveys, including the Farm Survey and the Second and Third Surveys of Consumer Requirements, were conducted during early 1944. These surveys are described in Table 1.

${ }^{4}$ In fact, most of the new Army divisions were organized from extant National Guard and Reserve divisions; and, the buildup of the Navy was initially provided by the Naval Acts of 1938 and 1940. 
Table 1. Surveys of Consumer Requirements conducted by the Bureau of the Census for the War Production Board

\begin{tabular}{|l|c|c|c|c|}
\hline Survey & First & Farm & Second & Third \\
\hline When & Fall 1943 & Spring 1944 & Spring 1944 & Spring 1944 \\
\hline Focus & nondurables & farm goods & clothing & Appliances \\
\hline
\end{tabular}

Source: Noyes C.E., Hilgard E.R. [1946].

The Third Survey, which focused on household appliances, revealed deferred demands for millions of appliances. These included 4.3 million washing machines, 4.0 million electric irons, 3.8 million refrigerators, 3.2 million cooking stoves, 3.2 million toasters, 2.7 million radios, 2.4 million vacuum cleaners, 2.3 million sewing machines, 1.5 million electric fans, 1.2 million heating stoves, 0.8 million water heaters, and lesser numbers of other household appliances [Noyes C.E., Hilgard E.R. 1946: 269]. There clearly were huge deferred demands, but the private sector already knew this.

Prior to the First Survey of Consumer Requirements, the Chamber of Commerce of the United States (1943) had already conducted two nationwide surveys of household buying intentions. There were yet other private-sector surveys and a variety of anecdotal information. The key findings of the Chamber surveys are presented in Table 2. They showed that increasing numbers of households planned to purchase automobiles and appliances, furniture and furnishings, and new homes. The surveys also showed that increasing numbers of households had accumulated substantial savings which would enable them to actually make these purchases.

Table 2. Surveys of Consumer Buying Intentions conducted by the Chamber of Commerce of the United States: Percent of households planning to make purchases

\begin{tabular}{|l|r|r|}
\hline & 1942 & 1943 \\
\hline Furniture and furnishings & 18.3 & 18.4 \\
Automobiles and appliances & 32.3 & 49.7 \\
New homes & 2.9 & 4.4 \\
Savings in excess of 10 percent of income & 43 & 51 \\
\hline
\end{tabular}

Source: Chamber of Commerce of... [1943]. 
During November and December 1943, polls by Gallup and Roper found that 74 percent and 66 percent of Americans planned on making one or more major purchases when the war ended [these and other public polls can be found in Cantril H., Strunk M. 1951]. Most frequently mentioned were cars, homes, furniture, refrigerators, other appliances, and clothing.

Also during 1943, several publishing houses began to assemble massive panels of consumers in order to monitor buying plans in detail. These details included brand consciousness and preferred shopping places. Why such detail? So, business could act on the information when the opportunity presented itself. The Curtis Publishing Co., for example, assembled a consumer panel aggregating 30,000 households from among the readers of the Saturday Evening Post, Ladies' Home Journal and Country Gentleman [these and other business surveys can be found in various issues of the Journal of Marketing 1943-1948]. Not all the buying plans uncovered by these surveys panned out. Far less than 45 percent of business and professional persons bought a private airplane or helicopter after the war, as was indicated by one survey.

Deferred demand was also indicated by the deteriorating performance of price controls and rationing. Initially, these programs worked well. Production was high. Rationed goods were generally available. Local boards were able to accommodate special cases (Fortune 1943 and Katona G. 1945]. But, as the war continued, these programs frayed. Lowerpriced clothing disappeared [Alwyn-Schmidt W. 1944], effectively forcing consumers to buy higher-priced apparel. Surveys conducted by the National Opinion Research Center revealed increasing complaints of overpriced meat. From zero mentions of black markets in gasoline in surveys conducted during 1942, 10 percent or more mentioned such black markets in surveys conducted during 1944. A survey of New York City shoppers revealed that a large majority had made at least some purchases in the black market [Survey... 1944]. Congressional testimony indicated that between 15 and 50 percent of gasoline purchases involved counterfeit ration coupons [Hearing... 1944], as did a similarly large percentage of meat purchases [Senate Hearing... 1946].

Along with the black market in ration coupons came organized crime. Dealing in counterfeit and stolen ration coupons went along nicely with such things as illegal gambling, prostitution, extortion, union racketeering, political corruption and gangland murder. In Connecticut, Salvatore 
Annunziato, known as "Midge," and his brother "Onions" found the black market in ration coupons to be a gold mine [Hoffman C. 2009].

In spite of much higher income and employment, only 13 percent said they were living better than before the war in 1943; and, only 9 percent said this in $1944 .{ }^{5}$ Rationing kept the standard of living down, as it was designed to. During 1944 and 1945, the Gallup Poll indicated that large majorities wanted rationing to end upon the war's conclusion. ${ }^{6}$

\section{POST-WAR DEPRESSION}

As discussed above, during the war it became apparent that households were building enormous deferred demands and the financial resources needed to act on those demands. Economists came to recognize that aggregate demand would be strong at the war's conclusion. The problem to economists - who were still captivated by the doctrines of secular stagnation and under-consumption [Hansen A.H. 1939, see also Backhouse, R.E., Boianovsky M. 2016] - was that this strong aggregate demand would not be sustainable.

"At the present time," said Samuelson P.A. [1943: 27], "there are clear indications of increasing optimism among our better-informed observers concerning the liklihood of a postwar boom of some duration." But, " ... the magnitude of the backlog is necessarily finite. If bunched into a short enough period, one can produce as large a boom as desired, but it will not last." [Samuelson P.A. 1943: 52]. Deferred demand cannot "be relied upon to initiate lasting prosperity. There is no justification to envisage a 'generation' or a decade of prosperity from this factor" [Samuelson P.A. 1943: 53]. Samuelson estimated the period of strong aggregate demand to last from 18 to 24 months.

Koopmans T. [1943] saw in the pent-up demand and liquid assets of the population the seeds of a boom that would subsequently usher in a bust. He therefore argued for continuation of price controls and rationing for consumer nondurables, and the extension of price controls and ra-

\footnotetext{
${ }^{5}$ In addition to growing weary of suppressed demand, civilians might have also been growing weary of the war itself.

${ }^{6}$ Support for post-war rationing appears to have collapsed during 1943. Early in the year, a majority supported post-war rationing [Post War Rationing... 1943: 1]. By the end of that year, a majority opposed [Post-war planning ... 1943: 928].
} 
tioning to consumer durables and housing. ${ }^{7}$ These policies were supposed to moderate the boom and, therefore, avoid the bust. Schlichter S.H. [1942] called for continuation of wage and price controls, as well as heavy taxation and government spending, in order to avoid a post-war depression.

For Moulton H.G. and Schlotterbeck K.T. [1942], the post-war period would feature either a boom or a depression, unless the economy were properly-guided by the government. Stead W.H. [1942] thought that massive new programs of government spending were needed to avoid a return to massive unemployment. Of particular concern was redistributing wealth from those who would save it to those who would spend it. Chase S. [1942] and Condliffe J.B. [1942] saw increasing government regulation to be a continuation of the New Deal. Laski H. [1943] considered an expanded role of government appropriate for a "mature economy."

During the war, economists foresaw that after the war the economy would relapse into the depressed economic conditions that preceded the war, delayed perhaps by a period of catch-up spending, unless the artificial prosperity of the war was continued through massive interventions.

During the year of demobilization, 1946, there was an increase in consumption spending, but this was only about one-fifth of the decrease in government spending [Vedder R.K., Gallaway L.E. 1993: 164]. It simply took time for factories to be converted to the production of civilian goods. Consumption spending was only larger than usual in 1947. In the meantime, millions of women were withdrawing from the labor force, and millions of men were making their way from the armed services to civilian employment. Production fell from 1945 to 1947, or maybe not. According to the U.S. Department of Commerce's estimate of Gross National Product as of 1960, production fell by 8 percent. According to its estimate as of 1990, production fell by 21 percent. ${ }^{8}$ But, according to Vedder and Gallaway, calculation of production is difficult during the period because of the lifting of price controls. They say there was practically no change over the twoyear period, with a small decrease during 1946 off-set by a similarly-sized increase during 1947 [Vedder R.K., Gallaway L.E. 1993: 159]. In real time, economists were explaining why forecasts of a post-war depression were so wrong [Klein L.R. 1946; Woytinsky W.S. 1947; and, Sapir M. 1949].

7 That is, to replace the rationing implicit in the suspension of production of consumer durables and housing, with explicit rationing.

${ }^{8}$ As of 2021, the Department of Commerce says that production declined by 12 percent from 1945 to 1947. 


\section{TIME SERIES OF EXPECTATIONS}

Toward the end of the war, poll-taking organizations started asking whether people expected a relapse into depression, as was being predicted by economists. The Roper Poll periodically asked would there be "a widespread business depression" within ten years following the war. The National Opinion Research Center asked if there would be "a great deal of unemployment, a medium amount, or only a little" within five years following the war. The exact questions differed as to the timing and depth of a possible future downturn in the economy. Table 3 gives examples of these questions.

Deriving a time series from data such as is shown in Table 3 is a challenge and may only be possible by making some assumptions. These assumptions concern (1) the difference in expecting a recession next year versus expecting one further into the future, (2) the difference in expecting a recession versus expecting a depression, and (3) how such expectations evolve over time.

1. Expectations of Recession. Let $\mathrm{p}_{1 \mathrm{t}}$ equal the percent of the population at time $t$ that expects a recession within the next year. Let $p_{y t}$ equal the percent of the population that expects a recession within the next y years for $y$ equal to $1,2,3,4,5$ and 10. Let $p_{y t}=r_{y} p_{1 t}+\left(1-r_{y}\right) p$ where $1=r_{1}>r_{2}>$ $r_{3}>r_{4}>r_{5}>r_{10}=0$, and where $p$ can be considered constant during a relatively short time period. Somewhat arbitrarily, $r_{2}$ was set equal to 0.8 , $r_{3} 0.6, r_{4} 0.4$ and $r_{5} 0.2$.

2. Expectations of Depression. Let $P_{y t}$ equal the percent of the population that expects a depression within the next y years. Since recessions are not as protracted depressions, $p_{y t}>P_{y t}$. Let $P_{y t}=\delta p_{y t}$ where $0<\delta<1$. A grid search indicated that $\delta$ equals 0.6 .

3. A Time Series of Expectations. Approximate $\mathrm{p}_{1 \mathrm{t}}$ through time with a quadratic spline, thus $p_{t 1}=a_{0}+a_{1} t+a_{2} t^{2}+a_{3} s_{3}{ }^{2}+a_{4} s_{3}{ }^{2}+\ldots a_{n} s_{n} t^{2}$ where $s_{n}=t-K_{n}$ for $n=3$ to $N$ if positive and otherwise zero, and $K_{n}$ are the knot points of the spline. Thus,

$$
Y_{i}=\sum_{j=1,8} b_{j} X_{j i}+e_{i}
$$

where $Y_{i}=$ percent of respondents in a survey conducted at time $t$ saying they expect a recession or a depression, or a fall in employment, or a rise in unemployment, or poor or falling business conditions within the next y years. 
Table 3. Examples of survey questions concerning expectations of an economic downturn

\begin{tabular}{|c|c|c|c|c|c|c|c|c|}
\hline Year & Mo. & Poll & Question & Sev. & Hor. & Yes & No & DK \\
\hline 1950 & 6 & Roper & $\begin{array}{l}\text { A real depression within the next } \\
\text { two years? }\end{array}$ & 1 & 2 & 29 & 47 & 24 \\
\hline 1950 & 3 & Gallup & $\begin{array}{l}\text { More or fewer people out of work } \\
\text { in the next few months? }\end{array}$ & 0 & 1 & 44 & 49 & 7 \\
\hline 1949 & 8 & NORC & $\begin{array}{l}\text { A real depression within the next } \\
\text { two or three years? }\end{array}$ & 1 & 2 & 31 & 61 & 8 \\
\hline 1949 & 7 & Gallup & $\begin{array}{l}\text { Truman says not balance budget } \\
\text { if a real depression is to be avoid- } \\
\text { ed }\end{array}$ & 1 & 2 & 38 & 44 & 18 \\
\hline 1949 & 6 & NORC & $\begin{array}{l}\text { A real depression within the next } \\
\text { six months? }\end{array}$ & 1 & 1 & 16 & 77 & 7 \\
\hline 1949 & 6 & NORC & $\begin{array}{l}\text { A real depression within the next } \\
\text { year or two? }\end{array}$ & 1 & 2 & 38 & 54 & 8 \\
\hline 1949 & 6 & NORC & $\begin{array}{l}\text { A real depression within the next } \\
\text { two or three years? }\end{array}$ & 1 & 3 & 50 & 39 & 11 \\
\hline 1949 & 3 & Gallup & $\begin{array}{l}\text { Now going into a real depression } \\
\text { or will business conditions im- } \\
\text { prove? }\end{array}$ & 1 & 2 & 30 & 59 & 11 \\
\hline 1949 & 2 & Gallup & $\begin{array}{l}\text { More or less unemployment by } \\
\text { this time next year? }\end{array}$ & 0 & 1 & 56 & 35 & 9 \\
\hline 1948 & 12 & Gallup & $\begin{array}{l}\text { A serious business depression } \\
\text { during the next four years? }\end{array}$ & 1 & 4 & 30 & 52 & 18 \\
\hline 1948 & 9 & Roper & $\begin{array}{l}\text { Within the next two years, a mod- } \\
\text { erate depression is likely }\end{array}$ & 0 & 2 & 51 & 33 & 16 \\
\hline 1948 & 8 & Gallup & $\begin{array}{l}\text { A serious business depression } \\
\text { during the next year? }\end{array}$ & 1 & 1 & 16 & 66 & 18 \\
\hline 1948 & 8 & Gallup & $\begin{array}{l}\text { A serious business depression } \\
\text { during the next four years? }\end{array}$ & 1 & 4 & 37 & 40 & 23 \\
\hline
\end{tabular}

Sev. (Severity): $1=$ depression, $0=$ recession; Hor. $=$ Time horizon in years.

Source: Cantril H., Strunk M. [1951].

$$
X_{1 i}=\delta \gamma
$$

where $\delta$ equals $\delta$ if question $\mathrm{i}$ involves a depression and otherwise 1 , and $r$ equals $r_{y}$ if question involves a time horizon of y years.

$$
\begin{aligned}
& X_{2 i}=\delta \gamma t \\
& X_{3 i}=\delta \gamma t^{2} \\
& X_{j i}=\delta \gamma s_{j}^{2} \text { for } j=4, N, \text { and } \\
& X_{8 i}=\delta(1-\gamma)
\end{aligned}
$$


Percent of the Public Expecting a Recession, 1945-1954

(inferred from surveys of public opinion) (NBER recessions shown in gray)

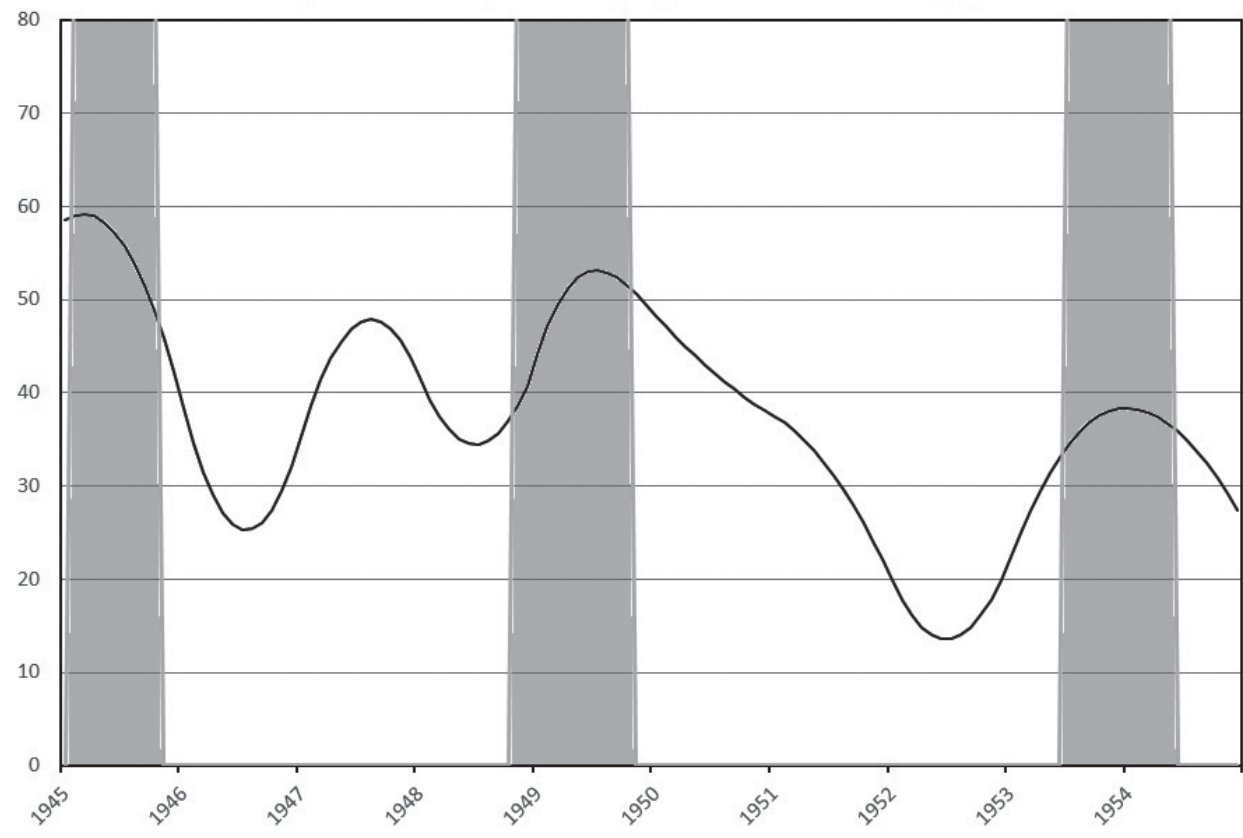

Figure 1. Percent of the Public Expecting a Recession, 1945-1954 inferred from surveys of public opinion (NBER recessions shown in gray)

Source: described in the text,

The parameters of the spline curve $\mathrm{a}_{\mathrm{j}}$ are the regression coefficients $b_{j}$ for $j=1,7$. From these, the time series $p_{1 t}$ can be formed. The parameter $p$ is the regression coefficient $b_{8}$.

The regression parameters $b_{j}$ are of no interest other than for being transformed into a time series that tracks the public's expectations of a recession. This time series is presented in Figure 1.

Figure 1 shows that the percent of the public expecting a recession rose during each of the three NBER recessions of the period 1945 to 1954. It also shows that this percentage rose during 1947, perhaps because of the warnings of a post-war depression by economists. However, there was no recession that year. 


\section{BUSINESS CONFIDENCE}

In 1946, the Roper Poll began a semi-annual survey of business on behalf of Fortune magazine. Recurring questions concerned business in general, sales, investment and employment. Respondents were asked whether they expected an increase, a decrease or no change. From the responses to these questions an optimism ratio (equal to the percent saying increase less the percent saying decrease) can be constructed. These optimism ratios are normed so that 0 would be extremely pessimistic, 50 neutral and 100 extremely optimistic. Thus transformed, the results of these surveys are displayed by the dashed line in Figure 2. As Figure 1 shows with the general public, Figure 2 shows that business turned somewhat pessimistic during 1947, but then quickly turned optimistic. Surveys of business, like those of the general public, indicate that a post-war economic downturn was expected in 1947, but such a thing did not materialize.

Business Confidence

( 0 = extremely pessimistic, $50=$ nuetral, $100=$ extremely optimistic)

(based on Fortune surveys)

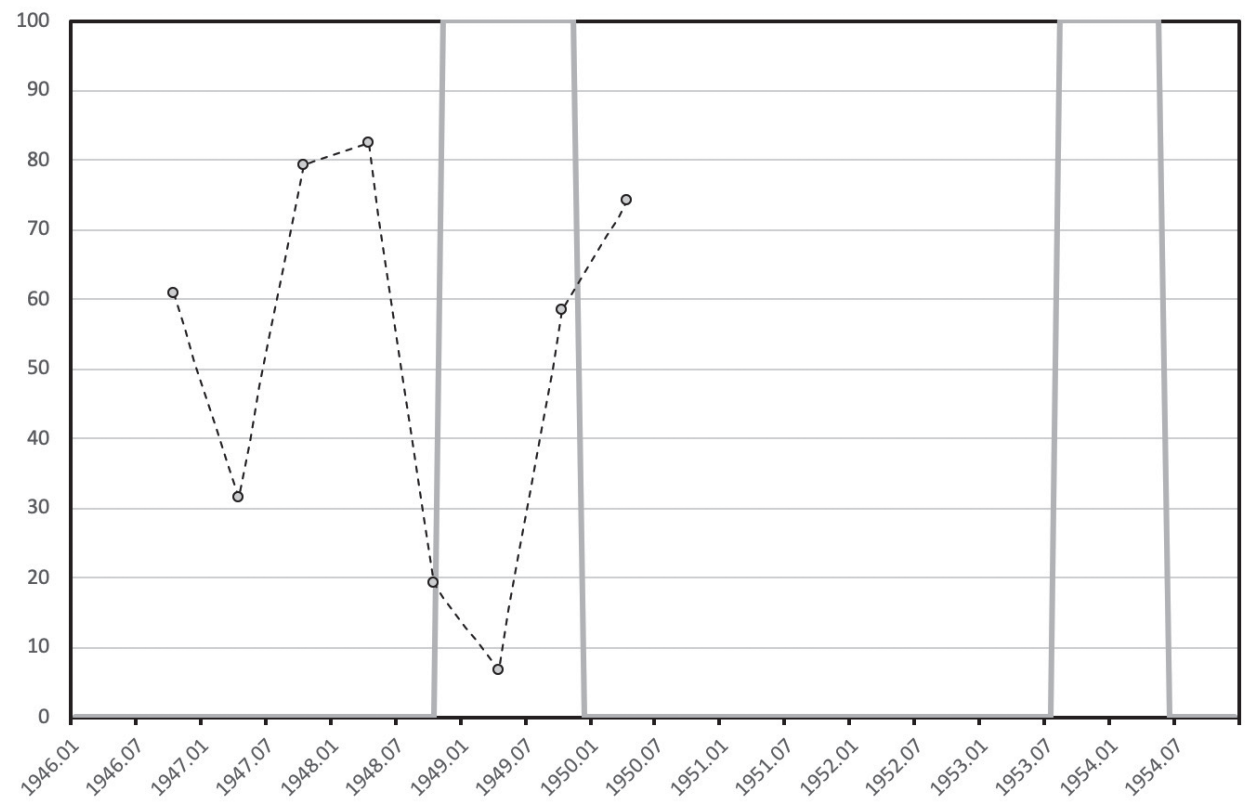

Figure 2. Business Confidence $(0=$ extremely pessimistic,

50 = neutral, 100 = extremely optimistic), based on Fortune surveys

Source: Fortune [various issues 1947 to 1950]. 


\section{ECONOMIC FORECASTS}

During 1946, Livingston, a journalist, began a semi-annual survey of several dozen economists, covering a variety of indicators at various time horizons. This survey has been continued by the Federal Reserve Bank of Philadelphia. Among the indicators about which respondents were asked has always been their forecasts of the Index of Industrial Production six months hence. The median response to this question is exhibited in Figure 3. It appears that economists, like business and the general public, thought in 1947 that the country was headed toward a post-war recession.

Going into 1947, the press was abuzz with discussion of a recession. A multi-part Associated Press story said, quoting the chief economist at Standard \& Poor's, that the second quarter was likely to be remembered. "as the beginning of the most widely-advertised recession on record" [Associated Press 1947a]. By July, the AP - quoting "some economists" described that month's jobs report "as driving the last nail in the coffin" of

Livingston Survey of Economists: \% Change in Industrial Production over next 6 months

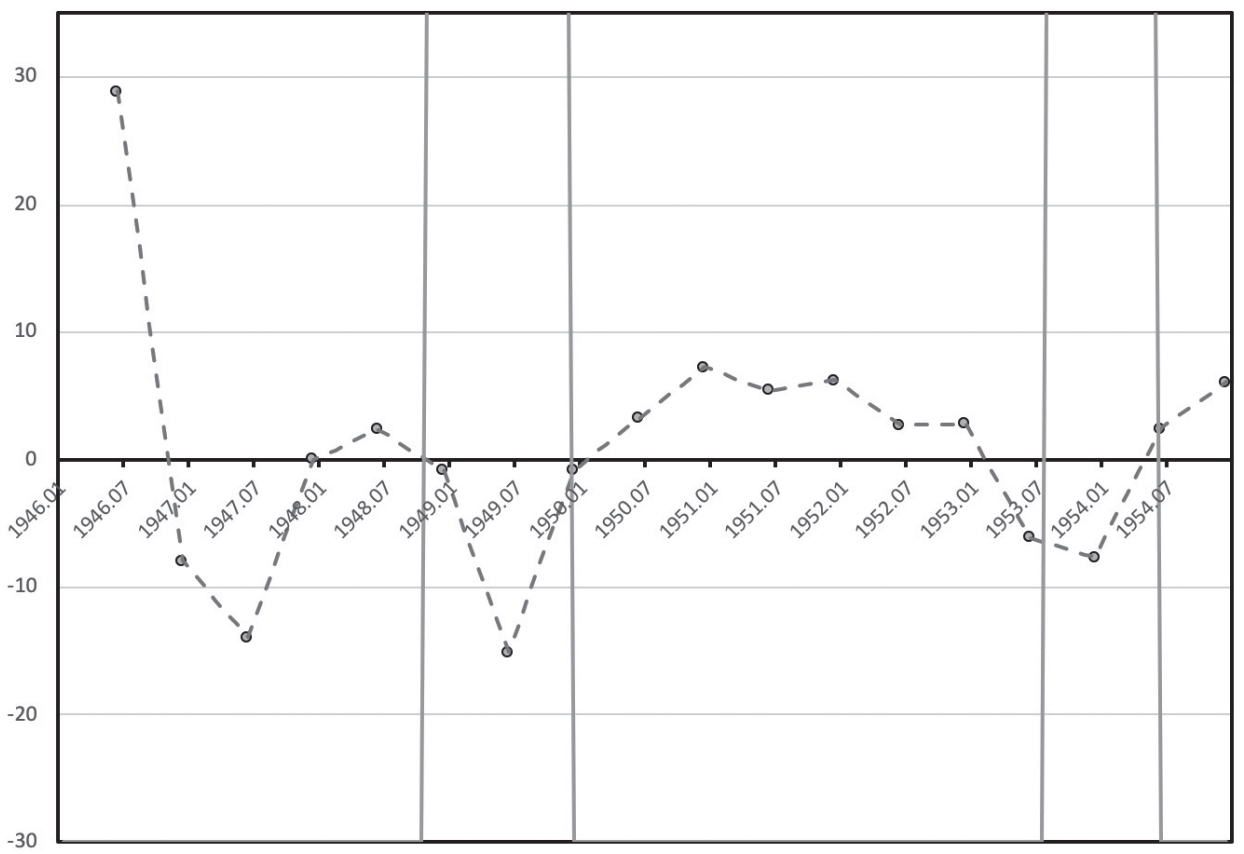

Figure 3. Livingston Survey of Economists: \% Change in Industrial Production over next six months

Source: Livingston Survey [1946-1954]. 
earlier forecasts of recession [Associated Press 1947b]. Stoked by the release of pent-up demand, and buoyed by more pragmatic policies, the economy relatively smoothly transitioned from a war footing to a peace-time orientation. The economy did not fall into a post-war depression.

\section{CONCLUSION}

As the end of World War II approached, economists resisted rapid demobilization and decontrol, and advocated commitment to policies designed to ensure full employment, if not full-blown socialism [Finer $\mathrm{H}$. 1945, Harris S.E. 1945, Lester R.A. 1945, and Wootton B. 1945]. ${ }^{9}$ Boulding K.E. [1945: 181] said there was a chronic deficiency in aggregate demand. While that chronic deficiency might be overcome by wars and new discoveries, "these things only seem to be a postponement." The failure of a postwar depression to materialize eventually brought forth a new paradigm, one that argued that it was possible to maintain full employment through aggregate demand management. ${ }^{10}$

In real time, business expressed an optimistic view. "New and expanding demands characterize a dynamic, progressive economy. Today's standard of living is always inadequate in light of tomorrow's needs..." argued the National Industrial Conference Board [1948: 24]. "Insurance, cosmetics and tobacco, to take some obvious examples, are now listed as necessities in wage-earner budgets. Automobiles, telephones and radios are found in the consumption expenditures of typical working families. In future decades, air-conditionings or even art works may be considered necessary ... As one industry catches up and settles down to a normal pace, others arise to carry the economy forward. Some such as television are already in sight; others are yet to be born."

9 See Bailey S.K. [1950], Brinkley A. [1995], Lekachman R. [1966] and Stein H. [1969] for accounts of the evolution of a proposed guarantee of full employment in 1945, into the mere goal of the same in the Full Employment Act of 1946. Ballard J.S. [1983], Goodwin C.D., Herren R.S. [1975] and Griffith R. (1989] describe reconversion policies more generally.

10 There was a hold-out group, the post-Keynesians, that continued to believe in the doctrines of secular stagnation and under-consumption. For them, the period following World War II consisted, first, of a period of reconstruction (1945 to 1950), and then a onetime "Golden Age" of capitalism (1950 to 1974) [Armstrong P. et al. 1991]. 
The end of World War II presented enormous decisions to the U.S. government and other governments. For many, the question was whether to continue with the policies that propelled employment and production to extraordinarily levels during the war, or risk returning to the depressed economic conditions that had persisted through the 1930s. To others, the question was whether to allow a market-oriented economy to restore the kind of continuous economic growth that had preceded the 1930s. Many economists argued for continued controls over the economy to prevent a post-war depression. As this paper shows, most people thought the country was heading to a recession, if not a full-blown depression. Nevertheless, the government proceeded to rapidly demobilize the returning soldiers and phase out its controls over the economy, and the economy quickly reorganized itself for peacetime.

\section{REFERENCES}

Alwyn-Schmidt W. (1944), 1944 and After, Department Store Economist, January.

Armstrong P., Glyn A., Harrison J. (1991 [1984]), Capitalism since 1945, Basil Blackwell, Cambridge, Mass.

Associated Press (1947a), Most economists see U.S. business boom ending by mid-year, Washington Evening Star, 10 April, A-18.

Associated Press (1947b), U.S. reaches goal of 60 million jobs, Wilmington Morning Star, 12 July.

Backhouse R.E., Boianovsky, M. (2016), Secular stagnation: The history of a macroeconomic heresy. European Journal of Economic History, 23, 6, 946-970.

Bailey S.K. (1950), Congress Makes a Law: The Story Behind the Employment Act of 1946, Columbia University Press, New York.

Ballard J.S. (1983), The Shock of Peace: Military and Economic Demobilization after World War II, University Press of America, Washington, D.C.

Bartels A.H. (1980), The Politics of Price Control: The OPA and the Dilemmas of Economic Stabilization, 1940-1946, Johns Hopkins University, Ph.D. Thesis.

Boulding K.E. (1945), The Economics of Peace, Prentice-Hall, New York.

Brinkley A. (1989), The New Deal Order and the Idea of the State [in:] Fraser S., Gerstle G. (eds.), The Rise and Fall of the New Deal Order, 1930-1980, Princeton University Press, Princeton, 85-121.

Brinkley A. (1995), The End of Reform: New Deal Liberalism in Recession and War, Knopf, New York.

Cantril H., Strunk M. (1951), Public Opinion, 1935-1946, Princeton University Press, Princeton, N.J.

Chamber of Commerce of the United States (1943), Third Progress Report of a Consumer Survey to measure postwar buying interest for the period immediately following the war's end.

Chase S. (1942), The Road we are Traveling, 1914-1942: Guide Lines to America's Future as Reported to the Twentieth Century Fund, Twentieth Century Fund, New York. 
Collins R.M. (1981), The Business Response to Keynes, 1929-1964, Columbia University Press, New York.

Condliffe J.B. (1942), Agenda for a Postwar World, W.W. Norton, New York.

Evans P. (1982), The Effects of General Price Control in the United States During World War II, Journal of Political Economy, 90(October), 944-966.

Fearon P. (1987), War, Prosperity and Depression: The U.S. Economy 1917-45, University Press of Kansas, Lawrence.

Finer H. (1945), Road to Reaction, Little Brown, Boston.

Folsom B.W., Folsom A. (2011), FDR Goes to War: How Expanded Executive Power, Spiraling National Debt, and Restricted Civil Liberties Shaped Wartime America, Simon and Shuster, New York.

Fortune (1943), The Fortune Survey, December.

Fortune (1947-1950), various issues.

Galbraith J.K. (1952), A Theory of Price Control, Harvard University Press, Cambridge, Mass.

Goodwin C.D., Herren R.S. (1975), The Truman Administration: Problems and Policies Unfold [in:] Goodwin C.D. (ed.), Exhortation and Controls: The Search for a Wage-Price Policy, 1945-1971, Brookings Institution, Washington, D.C.

Griffith R. (1989), Forging America's Postwar Order: Domestic Economics and Political Economy in the Age of Truman [in:] Lacey M.L. (ed.), The Truman Presidency, Cambridge University Press, Cambridge, Eng., 68-70.

Hamilton J.D. (1992), Was the deflation of the great depression anticipated? Evidence from the commodity futures markets, American Economic Review, 82 (1), 157-177.

Hansen A.H. (1939), Economic Progress and Declining Population Growth, American Economic Review, 29, March, 1-15.

Harris S.E. (1945), Price and Related Controls in the United States, McGraw Hill, New York.

Hearing Before a Subcommittee of the Committee on Interstate and Foreign Commerce: Petroleum Investigation (1944), U.S. Government Printing Office, Washington.

Higgs R. (2006), Regime Uncertainty: Why the Great Depression Lasted So Long and Why Prosperity Resumed after the War [in:] Depression, War and the Cold War, Oxford University Press, New York, 3-29.

Hoffman C. (2009), Midge Renault and the Heyday of the Mob, New Haven Independent, 25 August.

International Churchill Society (1940), "Fight them on the beaches, 4 June 1940."

Journal of Marketing (1943-1948), various issues.

Katona G. (1945), Price Control and Business, Principea Press, Bloomington, IN.

Kirkpatrick C.E. (1990), Strategic Planning for World War II. The Victory Plan in Context, Army History, 16 (Fall), 17-21.

Klein L.R. (1946), A post-mortem on Transition Predictions of National Product, Journal of Political Economy, 54, 289-308.

Klug A., Landon-Lane J.S., White E.N. (2005), How Could Everyone Have Been So Wrong? Forecasting the Great Depression with the Railroads, Explorations in Economic History, $42(1), 27-55$.

Koopmans T. (1943), Durable Consumers' Goods and the Prevention of Post-War Inflation, American Economic Review, 22, 4 December, 882-888.

Krooss H.E. (1970), Executive Opinion: What Business Leaders Said and Thought on Economic Issues, 1920s-1960s, Doubleday and Co, Garden City, N.Y.

Laski H. (1943), Reflections on the Revolution of our Time, Viking Press, New York.

Lekachman R. (1966), The Age of Keynes, Random House, New York. 
Lester R.A. (1945), Providing for Unemployed Workers in Transition: A Research Study of the Committee for Economic Development, McGraw-Hill, New York.

Livingston Survey (1946-1954), Federal Reserve Bank of Philadelphia.

Mathy G., Stekler H. (2017), Expectations and forecasting during the Great Depression: Real-time evidence from the business press, Journal of Macroeconomics, 53, September, $1-15$.

Mathy G., Stekler H. (2018), Was the deflation of the depression anticipated? An inference using real-time data, Journal of Economic Methodology, 25, April, 117-125.

Moulton H.G., Schlotterbeck K.T. (1942), Collapse or Boom at the End of the War, Brookings Institution, Washington, D.C.

National Industrial Conference Board (1948), Domestic Consumer Markets.

Noyes C.E., Hilgard E.R. (1946), Survey of Consumer Requirements [in:] Blankenship A.B. (ed.), How to Conduct Consumer and Opinion Research, Harper, New York, 259-273.

Post War Rationing Needed (1943), Toledo Union Journal, 13 June, 1.

Post-war planning is favored (1943), Commercial and Financial Chronicle, 11 February, 928.

Rockoff H. (1984), Drastic Measures: A History of Wage and Price Controls in the U.S., Cambridge University Press, Cambridge.

Romer C. (1993), The nation in depression, Journal of Economic Perspectives, 7, 19-40.

Samuelson P.A. (1943), Full Employment After the War [in:] Harris S.E. (ed.), Postwar Economic Problems, McGraw-Hill, New York, 27-53.

Sapir M. (1949), Review of Economic Forecasts for the Transition Period, Studies in Income and Wealth, 11, 275-351.

Schlichter S.H. (1942), Postwar Boom or Collapse, Harvard Business Review, September, $5-42$.

Senate Hearing Before Subcommittee of the Committee on Agriculture and Forestry on Senate Resolution (1946), Government Printing Office, Washington. U.S.

Stead W.H. (1942), Democracy Against Unemployment: An Analysis of the Major Problem of Post-War Planning, Harper, New York.

Stein H. (1969), The Fiscal Revolution in America, University of Chicago Press, Chicago.

Survey Shows 70\% in City Use Black Market, a Third of People Make it Regular Practice (1944), New York Times, 14 May.

Vedder R.K., Gallaway L.E. (1993), The Impossible Dream Come True [in:] Out of work: unemployment and government in twentieth-century America, Holmes and Meier, New York, 150-175.

Wootton B. (1945), Freedom under Planning, University of North Carolina Press, Chapel Hill.

Woytinsky W.S. (1947), What was wrong in forecasts of postwar depression? Journal of Political Economy, 55 (2), 142-151.

Clifford F. Thies, Ph.D., Eldon R. Lindsey Chair of Free Enterprise and Professor of Economics and Finance. Author or contributor to more than a hundred books, encyclopedia entries and articles in scholarly journals. His Global Economics: A Holistic Approach is available from Lexington Books. 